\title{
CONTRIBUTIONS TO THE HEPATICAE AND \\ ANTHOCEROTAE OF MIZORAM VIII \\ Bazzania hainanensis (Lepidoziaceae, Marchantiophyta), new record for India
}

\author{
S. K. Singh ${ }^{1}$ and S. Majumdar ${ }^{2}$ \\ ${ }^{1}$ Botanical Survey of India, Eastern Regional Centre, Shillong 793003, India \\ E-mail: sksbsinc@rediffmail.com \\ ${ }^{2}$ Botanical Survey of India, Central National Herbarium, Howrah 711 103, India \\ E-mail: shuvadeep.majumdar@gmail.com
}

(Received 11 August, 2014; Accepted 10 November, 2014)

\begin{abstract}
Bazzania hainanensis L.-P. Zhou et L. Zhang (Marchantiophyta) is recorded for the first time in India from the State of Mizoram (Myanmar border). It was earlier known from its type locality in China only. This is distinct amongst all earlier known species of the genus from Indian regions in having entire to weakly 2-3-lobed leaves, lobes when present, small tooth-like (1-2 cells long), as it has been described and illustrated here.
\end{abstract}

Key words: Bazzania hainanensis, India, Mizoram, new record

\section{INTRODUCTION}

Genus Bazzania is a member of the family Lepidoziaceae of Marchantiophyta, represented by about 100 species in the world with preponderance in the tropics and the Southern Hemisphere (Gradstein et al. 2001). Gottsche et al. (1845) reported the first members of the genus in India as Mastigobryum decurvum Nees based on the collection made by R. Wight from South India "peninsula Indiae orientalis", which is now a synonym of Bazzania praerupta (Reinw., Blume et Nees) Trevis. In the present state of our knowledge, 14 species, viz.: Bazzania appendiculata (Mitt.) S. Hatt., Bazzania assamica (Steph.) S. Hatt., Bazzania bhutanica N. Kitag. et Grolle, Bazzania bidentula (Steph.) Steph. ex Yasuda, Bazzania himalayana (Mitt.) Schiffn., Bazzania orientalis (Steph.) Parihar, Bazzania oshimensis (Steph.) Horik., Bazzania ovistipula (Steph.) Abeyw., Bazzania pearsonii Steph., Bazzania praerupta (Reinw., Blume et Nees) Trevis., Bazzania sikkimensis (Steph.) Herzog, Bazzania sumbavensis (Gottsche ex Steph.) Steph., Bazzania tricrenata (Wahlenb.) Trevis. and Bazzania tridens (Reinw., Blume et 
Nees) Trevis. are recorded under the genus from different bryogeographical regions of the country (Sharma and Srivastava 1993, Singh Deo and Singh 2014 and literature therein).

While documenting the Bryoflora (Hepaticae and Anthocerotae) of Mizoram in connection with the AAP project of the Botanical Survey of India, started in 2008, a terrestrial species of Bazzania were collected by one of the authors (SKS) from Champhai district, Mizoram - a region located at the Myanmar border. After careful study and scrutiny of literature it was identified as Bazzania hainanensis L.-P. Zhou et L. Zhang - a species earlier known from its type locality China only (Zhou et al. 2012a,b). The occurrence of this species in India extended its range of distribution within Eastern Asia and increased the number of Indian Bazzanias to 15. The studied specimens are deposited in the Cryptogamic Section of herbarium of the Botanical Survey of India, Eastern Regional Centre, Shillong (ASSAM).

\section{MORPHOLOGICAL AND ANATOMICAL DESCRIPTION}

\section{Bazzania hainanensis L.-P. Zhou et L. Zhang}

(Fig. 1)

Plants green when fresh; shoots 17-28 mm long, 2-3 mm wide; branching frequent, lateral pseudodichotomous, Frullania-type; flagelliform branches abundant on ventral surface with reduced leaves and underleaves; rhizoids not seen. Cross section of stem elliptical, $0.19-0.26 \times 0.26-0.33 \mathrm{~mm}, 9-12$ cells across diameter; undifferentiated, cortical cells subquadrate to rectangular or polygonal, 17.5-35.0 $\times 20-50 \mu \mathrm{m}$, yellowish to hyaline, thick walled; medullary cells polygonal or subquadrate to rectangular, (5.0-)10.0-32.5 $\times(5.0-)$ 10.0-37.5 $\mu \mathrm{m}$, yellowish to hyaline, thin or thick walled, trigones present, nodulose to indistinct. Leaves imbricate to contiguous, alternate, spreading, obliquely inserted, oblong, oblong-ovate, falcate, recurved ventrally, 1.0-1.5 $\mathrm{mm}$ long, $0.5-0.9 \mathrm{~mm}$ wide, widest just above the base, always longer than wide, apex narrow, obliquely truncate, usually entire, occasionally 2-3-lobed, lobes when present, small, tooth-like, 1-2 cells long, 1-2 cells wide, 1 cell uniseriate at apex, sinus shallow or almost absent, dorsal margin arched, base curved; apical to subapical leaf cells subquadrate to rectangular or polygonal, 8.0-22.2(-27.3) × 7.0-20.2(-22.2) $\mu \mathrm{m}$, thick walled, trigones indistinct; median leaf cells subquadrate to rectangular or polygonal, 18.2-40.4 × (14.1-)15.1-30.3 $\mu \mathrm{m}$, thick walled, with minute, nodulose trigones, basal leaf cells subquadrate to rectangular or polygonal, $26.3-55.5 \times 20.2-42.4 \mu \mathrm{m}$, thick walled with nodulose trigones; leaves near branch emergence narrowly or broadly triangular, 0.9-1.2 mm long, 0.6-0.8 mm wide at base, 1-lobed, lobes triangular, apex 


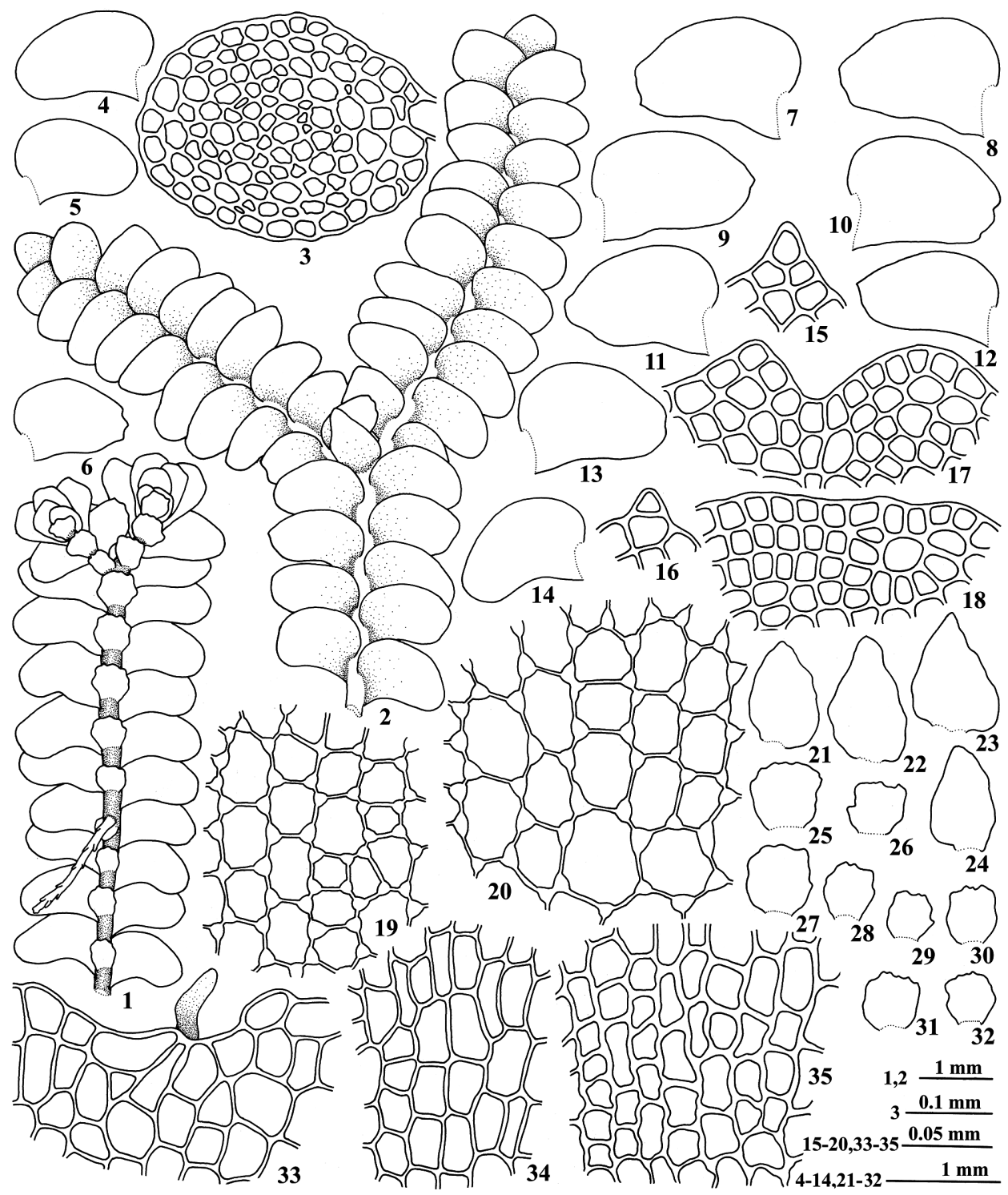

Figs 1-35. Bazzania hainanensis L.-P. Zhou et L. Zhang. $1=$ a portion of the plant in ventral view (rhizoids not drawn); 2 = the same in dorsal view; $3=$ cross section of stem; $4-14=$ leaves; $15-18=$ apical cells of leaf; $19=$ median cells of leaf; $20=$ basal cells of leaf; $21-24=$ leaf near branch emergence; $25-32=$ underleaves; 33 = apical cells of underleaf showing papillae; 34 = median cells of underleaf; 35 = basal cells of underleaf 
acute; cuticle smooth; oil bodies not seen. Underleaves distant, 1.2-2 times as wide as stem and closely appressed to it, connate with the leaves at one side or without connation, ovate to subquadrate, irregularly lobed, longer than wide or as long as wide or wider than long, $0.40-0.63 \mathrm{~mm}$ long, $0.40-0.63 \mathrm{~mm}$ wide, widest at apex, apex irregularly lobed, margins crenulate to irregularly lobed; hyaline slime papilla present at the apex as well as in lateral margins; apical underleaf cells subquadrate to rectangulate or polygonal, 5.0-13.1(-16.2) $\times 4.0-14.1(-20.2) \mu \mathrm{m}$, thin-walled, undulate with irregularly lobed, margin entire; median leaf cells subquadrate to rectangulate or polygonal, 15.1-43.4 $(-48.5) \times 7.1-23.2 \mu \mathrm{m}$, thin walled; basal underleaf cells smaller, subquadrate to rectangulate or polygonal, $12.1-34.3(-38.4) \times 7.1-20.2 \mu \mathrm{m}$, trigonous. Sterile.

Specimen examined: India, Mizoram, Champhai-Khawzawl, terrestrial. Lat.: $23^{\circ}$ 28' 06" N; Long.: $93^{\circ} 18^{\prime} 19^{\prime \prime}$ E; Alt.: 1,320 m a.s.l. Coll.: S. K. Singh and Party (120416), 24.02.2009 (ASSAM).

Distribution: India: Mizoram (present study), China (Zhou et al. 2012a, b), Bhutan and Nepal (Prof. Tamás Pócs: pers. comm., Jan. 2015).

\section{DISCUSSION}

B. hainanensis is characterised by falcate to ovate and truncate leaves, apex having entire to weakly 2-3-lobed leaves, lobes when present, small, tooth-like, 1-2 cells long, 1-2 cells wide and 1 cell uniseriate, median and basal cells with nodulose trigones; underleaves closely appressed to stem; cell walls trigonous, with hyaline papillae at apex and margins. The presence of truncate leaf apex usually without lobe, when present only one in number distinguishes it from other species of the genus Bazzania occurring in India. Some minor variations, like $0-1$-lobed per leaf, tooth-like lobe 1-2 cells long, underleaves not connate or connate only on one side of leaves, without denticulations are observed in Indian plants, while the type specimen is represented by weakly 0-3-lobed, only one-cell-long lobes, underleaves connate on both sides of leaves and with 1-2 cells long denticulations (Zhou et al. 2012a). Apart from minor variations the Indian and Chinese plants are morphologically similar.

Among the Indian species, Bazzania hainanensis resembles B. tridens (Reinw. et al.) Trevis. in ovate to oblong leaves; underleaves nearly 2 times wider than the stem, always longer than wide, connate with the leaves at one side or without connation, closely appressed, quadrate to subquadrate, thin walled, hyaline; but differs in having stem 10-15 cells across, cortex differentiated, consisting of 2-3 cell layers and leaf with truncate apex, distinctly (2-)3(-4)-lobed, 
which lobes are 3-15 cells long, 3-13 cells wide at base, underleaves imbricate and cuticle verrucose.

It also resembles the Australian Bazzania fasciculata (Steph.) D. Meagher in having undifferentiated stem, falcate-ovate leaves with an arched dorsal margin and incurved ventral margin, truncate apex entire to very weakly 3-lobed, the lobe apices obtuse and underleaves narrowly connate with the leaves on both sides; but the latter can be easily distinguished by possessing square to rhombic or hexagonal median leaf cells and always wider than underleaves long and repand margins (Meagher 2008).

Acknowledgements - The authors are grateful to Dr P. Singh, Director, Botanical Survey of India, Kolkata for facilities; Dr D. K. Singh, Scientist F, BSI, Kolkata, India for mentoring us; Dr A. A. Mao, HOO, Eastern Regional Centre, Shillong, India for encouragement and Forest Department, Mizoram for logistic support during the field exploration. One of the authors (SKS) is also extending sincere thanks to his team members for accompanying him during field exploration.

\section{REFERENCES}

Gottsche, C. M., Lindenberg, J. B. G. and Nees von Esenbeck, C. G. (1845): Synopsis Hepaticarum. Fasc. 2. - Meissner, Hamburg, pp. 145-304.

Gradstein, S. R., Churchill, S. P. and Salazar-Allen, N. (2001): Guide to the bryophytes of tropical America. - Memoirs New York Bot. Garden 86: 1-577.

Meagher, D. (2008): Studies on Bazzania 1. Some new and little known species from Australasia. - Nova Hedwigia 86(3-4): 477-495. doi: 10.1127/0029-5035/2008/0086-0477

Sharma, D. and Srivastava, S. C. (1993): Indian Lepidoziineae, a taxonomic revision. - Bryophyt. Biblioth. 47: 1-353.

Singh Deo, S. and Singh, D. K. (2014): Bazzania bhutanica (Lepidoziaceae, Marchantiophyta) - a critically endangered liverwort recorded in Indian bryoflora. - Lindbergia 37: 42-46.

Zhou, L.-P., Zhang, L. and Xing, F.-W. (2012a): The genus Bazzania in China and adjacent regions. 1. Bazzania dulongensis L.-P.Zhou \& L. Zhang sp.nov. and Bazzania hainanensis L.P. Zhou \& L. Zhang sp. nov. - J. Bryol. 34(1): 22-31. doi: 10.1179/1743282011Y.0000000039

Zhou, L.-P., Zhang, L. and Xing, F.-W. (2012b): Taxonomical review of Bazzania (Lepidoziaceae, Marchantiophyta) in China. - J. Fairy Lake Bot. Gard. 11(2): 1-62. 